Debating Diya: Indirect Rule and the Transformation of Islamic Law in British Colonial Northern Nigeria

Rabiat Akande

Follow this and additional works at: https://digitalcommons.osgoode.yorku.ca/all_papers

Part of the Constitutional Law Commons, and the Religion Law Commons 
Rabiat Akande 11/02/2021

Draft; do not cite without author's permission

\section{DEBATING DIYA: INDIRECT RULE AND THE TRANSFORMATION OF ISLAMIC LAW IN BRITISH COLONIAL NORTHERN NIGERIA}

\section{Introduction}

"Indirect rule is, indeed, a kind of inversion of the constitutional trick we have learned in England; the autocratic Emir retains nearly all his powers in theory while in practice, behind the curtain, he is checked and propelled, not by a ministry, still less by a democracy, but by an unobtrusive, kindly, middle-aged Englishman who derives his authority from the military power and wealth of Great Britain"'1

Leading academic authority on British imperial governance, Dame Margery Perham famously made the above remark on the workings of indirect rule in Northern Nigeria - the colonial state resulting from the 1903 British conquest of the West African Sokoto Caliphate. ${ }^{2}$ First emerging on the heels of the 1857 mutiny in British India, British colonial indirect rule had a long and checkered history predating its arrival in Nigeria. The dominant understanding of the Indian rebellion was that of a revolt against empire's anglicizing project with the consequence that it spurred the colonial state to turn to governing colonial populations through native institutions within and beyond India. Indirect rule was never coherent, nor uniform across colonial holdings; yet, it notoriously institutionalized the co-option of indigenous rulers and laws to further the ends of empire. ${ }^{3}$

\footnotetext{
${ }^{1}$ Perham, West African Passage, 66

${ }^{2}$ The other major empire that was incorporated into the British Protectorate of Northern Nigeria was the Kanem Bornu Kingdom. However, much of Kanem Bornu was carved into contiguous French imperial possessions around the Lake Chad Basin area. For this reason, as well as the undisputed fact that Sokoto was "the largest, most heavily populated, most complexly organized and wealthiest system in nineteenth century west Africa," references to precolonial institutions in this article will focus on the Sokoto Caliphate. Watts, Michael J. Silent violence: Food, famine, and peasantry in northern Nigeria. Vol. 15. University of Georgia Press, 2013. For classical accounts of the Sokoto caliphate, see Last, Murray. The Sokoto Caliphate, Humanities Press, 1967, Mervyn Hiskett, The Sword of Truth: The Life and Times of the Shehu Usuman Dan Fodio (New York: Oxford University Press, 1973) h

${ }^{3}$ The background architecture/ lever of compulsion remained even where indirect rule was impracticable due to resistance of indigenous institutions [or even ideological disinclination of colonial administrators from governing though indigenous institutions]. the colonial state enacted its agenda without the aid of local intermediaries. Direct and indirect rule were, therefore, to borrow Mahmood Mamdani's words, "two faces of power." Mahmood Mamdani, "Historicizing Power and Responses to Power: Indirect Rule and its Reform." Social Research (1999): 859886. 862. Nevertheless, much of everyday imperial governance was carried out through the aid of indigenous institutions.
} 
Indirect rule was, however, not merely rule through indigenous institutions; it necessarily entailed the governance of those indigenous institutions. ${ }^{4}$ There has, therefore, been much commentary on the impact of colonial rule on precolonial laws and institutions of colonized societies. ${ }^{5}$ Scholarly discourse on the fate of Muslim societies in the colonial encounter follows the broader contours of the general debate over colonialism in some respects; in other ways, however, this body of work reflects the particularities of the encounter of western colonialism with the unique history of Islamic law.

One view evinced by the works such as Waeel Hallaq's is that the colonial encounter radically transformed law and institutions with the impact that the Islamic law emerging from the colonial encounter was at odds with its precolonial form. ${ }^{6}$ According to this narrative, the colonial state (and its postcolonial iteration) invoked Islamic law and institution to legitimize itself while in fact transforming them beyond recognition. This was notably through altering the precolonial constitutional balance between jurists fiqh and political authorities' siyasa. The colonial state, it is argued, arrogated the power to determine the content of Islamic law as in Warren Hastings' colonial India; yet the siyasa jurisdiction assumed by the state to legitimate its power was

\footnotetext{
${ }^{4}$ R. Akande, Secularizing islam, , Mahmood Mamdani, Citizen and Subject: Contemporary Africa and the Legacy of Late Colonialism (Princeton, NJ: Princeton University Press, 1996); and Jonathan Reynolds, "Good and Bad Muslims: Islam and Indirect Rule in Northern Nigeria," International Journal of African Historical Studies (2001): 601-18; Scott Alan Kugle, "Framed, Blamed and Renamed: The Recasting of Islamic Jurisprudence in Colonial South Asia," Modern Asian Studies 35 (2001): 257-313; Michael R. Anderson, "Islamic Law and the Colonial Encounter in British India," in Institutions and Ideologies: A SOAS South Asia Reader, ed. David Arnold and Peter Robb (London and New York: RoutledgeCurzon, 2013), 165-185. Iza R. Hussin, The Politics of Islamic Law: Local Elites, Colonial Authority, and the Making of the Muslim State (Chicago: University of Chicago Press, 2016)

${ }^{5}$ That broader scholarship reflects three views on colonialism's governance through law: the first is that law, in the colonial encounter, is a tool of domination, one harnessed to suppressed colonial populations for the ends of colonial rule. The second view is that law, rather than being an instrument of domination, was a tool harnessed by the colonized to resist subjugation. The third view, a synthesis of the first two, is that law was both and instrument of domination and a tool deployable by the colonized to resist rule. See Comaroff, colonialism, culture and law: a foreword.

${ }^{6}$ See Hallaq, Wael. The impossible state: Islam, politics, and modernity's moral predicament. Columbia University Press, 2012; Hallaq, Wael B. Sharī'a: theory, practice, transformations. Cambridge University Press, 2009.

Moustafa, Tamir. Constituting religion: Islam, liberal rights, and the Malaysian state. Cambridge University Press, 2018; see izza hussin, the politics of Islamic law. Brinkley Messick, The Calligraphic State (California, 1993); QuraishiLandes, Asifa. "Islamic Constitutionalism: Not Secular, Not Theocratic, Not Impossible." Rutgers JL \& Religion 16 (2014): 553. For the argument that colonial rule eroded islamic law in northern nigeria, see Mahmud, Abdulmalik Bappa. "A brief history of Shari'ah in the defunct Northern Nigeria." (1988); Yadudu, Auwalu H. "Colonialism and the Transformation of Islamic Law: In the Northern States of Nigeria." The Journal of Legal Pluralism and Unofficial Law 24, no. 32 (1992): 103-139; Eltantawi, Sarah. Shari'ah on Trial: Northern Nigeria's Islamic Revolution. Univ of California Press, 2017; Ajetunmobi, Musa Ali. Shariah Legal Practice in Nigeria 1956-1983. Kwara State University Press, 2018.
} 
disjointed from the shari'a — as expounded by jurists and lived in precolonial practice. Deprived of its Shari'i origins, therefore, siyasa ceased to be bound by its Shari' constitutional boundaries ("siyasa sharriya"), becoming, instead, a colonial statist siyasa. ${ }^{7}$

Another view, however, suggests that precolonial Islamic juristic practice did not admit the fine line between fiqh and siyasa drawn by the above position. Sharia, this view suggests, has always been "positioned at the intersection of both legal discipline and governance." ${ }^{8}$ Fiqh expositions of the Sharia did not therefore always rule. Rather than a juristocracy, this view suggests that precolonial times witnessed expansive, and sometimes even capacious exercise of siyasa. Siyasa, in essence, was not always siyasa shariyya in practice. Anver Emon for instance asserts that behind jurisprudence "lies a host of background assumptions that link the Sharīa's doctrines to the institutional and political framework within which those rules were intelligible." By revealing the influence of pre-colonial Sultanic/ caliphal authority on jurisprudence and everyday judging, works in this strand suggest that the gradual disjuncture of siyasa from the Sharia predated the relations of power ushered in by western colonialism. ${ }^{10}$ This position consequently dissents from the Hallaqian view that colonialism upset the pre-colonial balance of the fiqh and siyasa, and that it freed siyasa from Shari' limits. Rather than focus on colonialism's impact on the constitutional structure of Islamic legal governance, proponents espousing the

\footnotetext{
${ }^{7}$ See Kendhammer, Brandon. Muslims talking politics: Framing Islam, democracy, and law in Northern Nigeria. University of Chicago Press, 2016.

${ }^{8}$ Ellis et al, supra. See also Naveeda Khan, Muslim Becoming (Duke, 2012), Noah Salomon, For Love of the Prophet.Transformations (Cambridge, 2009); Tamir Moustafa "The Judicialization of Religion," Law \& Society Review,2018. Hikmet Kocamaner, "Regulating the Family through Religion: Secularism, Islam, and the Politics of the Family in Turkey," American Ethnologist, 2019, Morgan Clarke, Islam and Law in Lebanon (Cambridge 2018). Emon infra.

${ }^{9}$ See Emon, Anver M. "Religious minorities and Islamic law: Accommodation and the limits of tolerance." Islamic law and internafional human rights law (2012): 323-343. Emon for instance cites an analogy given by Shafi scholar, Abu Al Ma'ala Al Juwayni to illuminate the state's prerogative over the law. The analogy involves a married couple: while the husband adheres to the Hanafi school of thought, the wife is of Shafi persuasion and both are mujtahid (that is, both are equally capable of conducting expert legal reasoning in their respective schools' jurisprudence). Were the husband to pronounce divorce in a fit of anger, such a divorce would be invalid under Hanafi law but valid under Shafi law. Al Juwayni submits that in the disagreement bound to ensue, the parties will table the dispute before a qadi whose decision becomes binding, not because it accords with the ruling of either school of jurisprudence, but rather because the judicial institution is authorized-by the state. See Abu Al Ma'ala Al Juwayni, Kitab al ljtihad min Kitab al Talkhis. Ed. 'Abdul-Hamid Abu Zunayr. Damscus: Dar Al Qalam 1987

${ }^{10}$ Emon, Anver M., Emon, Anver M. Religious pluralism and Islamic law: Dhimmis and others in the Empire of Law. Oxford University Press, 2012; Ayoub, Samy A. Law, Empire, and the Sultan: Ottoman Imperial Authority and Late Hanafi Jurisprudence. Oxford University Press, 2019.
} 
second view turn their searchlight elsewhere including on the transformation of substantive rules and the impact of legal pluralism, to mention a few examples. ${ }^{11}$

Without slipping into the tendency within the Hallaqian strand to idealize the constitutional practice of precolonial Muslim polities, one may, nevertheless, discern much by paying attention to colonialism's impact on the allocation of power between political authorities and jurists, and ultimately, of the relations between the former's siyasa and the Sharia. In fact, paying attention to this structural allocation is crucial not only for shedding light on the "what"- the transformation of substantive rules, but perhaps even more importantly, on the "how" - the mode by which that transformation occurred. Answering this question calls for a careful consideration of the historical specificities of the colony in question. After all, while the longer global history of Islamic law is crucial to understanding Islamic legal ideas as they circulated across the world and into the area that would become Northern Nigeria, Islamic legal practice is contextual. To interrogate colonialism's impact on Northern Nigerian Islamic law is therefore to pay careful attention to the encounter of precolonial caliphal institutions (and legal practice) with the distinct expression of British colonial rule in that colony.

In precolonial Northern Nigeria, siyasa was contained by the Shari' constitutional boundary. ${ }^{12}$ This is not to romanticize precolonial practice-cases where extra-juristic considerations of governance and politics trumped juristic understandings of the Sharia are not hard to find. Nevertheless, those deviations were understood as ultira vires and the state's siyasa was bound by Shari' constitutional boundaries however much state-appointed judge-jurists disagreed over the content of the Sharia. Understanding the theoretical sharia limits of the siyasa was therefore crucial to apprehending the discursive limits of precolonial juristic debates. The standards for setting these limits were radically reconfigured during colonial rule. Yet, because British indirect rule was premised on an exaggerated, yet false, deference to precolonial institutions, the colonial state was mandated to maintain appearances of upholding the caliphal constitutional structure even while it simultaneously subverted the caliphal design in pursuit of its projects.

\footnotetext{
${ }^{11}$ Emon, Anver M., Emon, Anver M. Religious pluralism and Islamic law: Dhimmis and others in the Empire of Law; Ayoub, Samy A. Id

${ }^{12}$ For the constitutional arrangement of the precolonial Sokoto caliphate, see J. S Trimingham, A History of Islam in West Africa; Ajetunmobi, Musa Ali. Shariah Legal Practice in Nigeria 1956-1983. Kwara State University Press, 2018, 24-30 See further I.A.B Balogun, The Life and Works of Uthman Dan Fodio. For the Sokoto caliphate in particular, see Last id, Hiskett, Id
} 
It is with the foregoing in mind that this article interrogates the colonial transformation of the institution of diya, the payment of compensation for unlawful killing, in British Northern Nigeria. The abolition of diya was the outcome of a debate over who had the prerogative to determine the response for crimes directed at the person: the aggrieved individual or the state. Prominent Muslim jurists argued in favor of the former, citing source texts and the precolonial practice that gave life to the textual prescriptions. Colonial administrators, on the other hand, insisted that the response to crimes against the person was the prerogative of the state and that interpersonal resolution of such matters challenged the authority of empire - the locus of siyasa in colonial times. At the same time, the peculiar design of Northern Nigerian indirect rule meant that statutory, and therefore, unequivocal elimination of diya, remained elusive. I trace the contours of the debate over the fate of diya as a lens through which one may apprehend the impact of colonial indirect rule not only on the substantive rules of Islamic law but even more importantly, on the constitutional structure allocating authority between political authorities and jurists. I therefore foreground the procedural transformation that enabled the alteration of substantive juristic principles of diya. Departing from the tendency to focus on the transformation of substantive rules, the Northern Nigerian story shows that understanding the procedure of reform, the "how," is crucial to apprehending the fate of Islamic law in the colonial encounter. That procedural transformation was, in the end, the genius of colonial indirect rule and the bane of Islamic law in British Northern Nigeria.

\section{I: Governing Through Emirs}

Received accounts present Northern Nigeria as a unique manifestation of British indirect rule. ${ }^{13}$ Save in parts of the Aden Protectorate, only in Northern Nigeria did the colonial state apply Islamic law not just as personal, but also as criminal law. Historians interpret this peculiar feature of Northern Nigerian indirect rule as a reflection of the extreme seriousness with which colonial administrators took the pledge to administer the territory through pre-existing institutions. ${ }^{14} \mathrm{On}$

13 J.N.D., Anderson, Islamic Law in Africa (Oxon: Routledge, 2013), Schacht, Joseph. "Islam in Northern Nigeria." Studia Islamica 8 (1957): 123-146; AHM Kirk Greene, "The Principles of Native Administration in Nigeria: Selected Documents 1900-1947. Edited and Introduced by AHM Kirk-Greene. Oxford University Press, 1965 ${ }^{14}$ See Fika, Adamu Mohammed. The Kano civil war and British over-rule, 1882-1940. Oxford University Press, 1978; Ikime, Obaro. "Reconsidering indirect rule: The Nigerian example." Journal of the Historical Society of Nigeria (1968): 
the morning of March 15, 1903, the day following the conquest of Northern Nigeria's pre-colonial Sokoto Caliphate, the head of the imperial army, Colonel Frederick Lugard, extended a guarantee to the chiefs ("emirs") on behalf of the British Crown that "Government will not interfere with Islam." 15 As first colonial Governor, Lugard went on to direct that emirs' oath of office reflect an exemption from complying with colonial directives "contrary" to Islam. ${ }^{16}$ Lugard and his successors proceeded to govern the territory through emirs as well as other caliphal institutions, especially alkalai ("judges") ${ }^{17}$ and alkalai courts purporting to apply Islamic law. Consequently, there is no dearth of accounts suggesting that colonial rule perpetuated pre-colonial caliphal institutions and its Islamic legal practice. Indeed, some accounts go beyond this claim to assert that colonial rule did not merely preserve pre-existing institutions but also reified those institutions. Writing in 1951, Joseph Schacht, prominent twentieth century western scholar of Islamic law, denounced what he regarded as colonial indirect rule's undue deference to Islamic law. ${ }^{18}$ The consequence of this attitude, Schacht argued was that the state "froze Islamic law "theory" in a deviation from the laxity of practice that characterized Muslim societies. Cohering with Schacht's diagnosis, Professor JND Anderson of the School of Oriental and African Studies in London who would come to have immense influence on the Colonial Office and on the ultimate trajectory of Northern Nigerian Islamic law, argued that the colonial state reified Islamic law. Not a few commentators continue to espouse this view. ${ }^{19}$ As a mark of this reputation of Northern Nigeria as

421-438. See also Kukah, Matthew Hassan. "Religion, politics and power in Northern Nigeria." (1993) Anderson Id, Schacht Id

${ }^{15}$ Report of the Native Courts (Northern Provinces) Commission of Inquiry, Laid on thetable of the House of Representatives as Sessional Paper No. 1 of 1952 (Lagos: Federal Government Printer, 1952)

16 "I swear in the name of God well and truly to serve His Majesty King George V and his representative, the Governor of Nigeria, to obey the laws of Nigeria and the lawful commands of the Governor, and of the Lieutenant Governor, provided they are not contrary to my religion and if they are so contrary I will at once inform the Governor through the Resident..." Lugard, Frederick JD, The Dual Mandate in British Tropical Africa. Edinburgh; London: W. Blackwood, 1922, 212

${ }^{17}$ Hausa, from the Arabic "al qadi"

18 Joseph Schacht, "Investigation into the Application of Islamic law in Nigeria" [1951], CO 927/158/6 National Archives, UK. Schacht, Joseph. "Islam in Northern Nigeria." Studia Islamica 8 (1957): 123-146.

19 Ochonu, Colonialism by Proxy. See also Vaughan, Olufemi. Religion and the Making of Nigeria. Duke University Press, 2016; Fika, Adamu Mohammed. The Kano civil war and British over-rule, 1882-1940. Oxford University Press, 1978; Ikime, Obaro. "Reconsidering indirect rule: The Nigerian example." Journal of the Historical Society of Nigeria (1968): 421-438; Kukah, Matthew Hassan. "Religion, politics and power in Northern Nigeria." (1993); Ayuba, Kukah. See however Auwalu H. Yadudu, "Colonialism and the Transformation of the Substance and Form of Islamic Law in the Northern States of Nigeria," Journal of Law and Religion 9, no. 01 (1991): 17-47. Abdulmumini A. Oba, "Islamic Law as Customary Law: The Changing Perspective in Nigeria," International and Comparative Law 
a colonial territory with an exaggerated deference to pre-colonial caliphal institutions, Frederick Lugard, who designed the Northern Nigerian model of indirect rule, is regarded as the "high priest of indirect rule." ${ }^{20}$ Lugard, who first introduced Northern Nigeria into the colonial territory exoticized caliphal institutions as ideal-for Africa. Writing in his magnus opus, The Dual Mandate, the colonial administrator declared:

"[Islam] is a religion incapable of the highest development but its limitations clearly suit the limitations of the people. It has undeniably had a civilizing effect, abolishing the gross forms of pagan superstitions and barbarous practices and adding to the dignity and self-respect and selfcontrol of its adherents. Its general effect has been to encourage abstinence form intoxicants, a higher standard of life and decency, a better social organization and tribal cohesion and a welldefined code of justice."21

Beyond this orientalizing tendency, Northern Nigerian indirect rule was also driven by an exigency-administrators found the governance design an inexpensive mode of administering a territory $320,000 \mathrm{sq} \mathrm{mi}$ in size, and nine million in population with only 100 British officers on ground. ${ }^{22}$ Under these circumstances, colonial administration depended on pre-existing institutions to govern the territory. Nevertheless, colonial indirect rule did not reify pre-colonial institutions as commentators like Anderson and Schacht assert. For all its ostensible deference to native institutions, indirect rule, in its Lugardian design and in later iterations, privileged the ends of empire.

As an expression of empire's unrivalled authority, colonial rule radically transformed Islamic law, including Islamic criminal law in general, and as it pertained to diya in particular. That the colonial

Quarterly 51, no. 04 (2002): 817-850. Sarah Eltantawi, Shari'ah On Trial: Northern Nigeria's Islamic Revolution (Oakland: University of California Press, 2017)

For instance, BJ Dudley, ikime and fika (p. 16 book manuscript notes) (as missionaries) argue that emirs powers and that of Islamic institutions as a whole was reified by indirect rule [e.g some say emirs had powers but not alkalai [put in footnote that schacht and Anderson think islam was reified but emirs rendered powerless]

${ }^{20}$ Report of the Native Courts (Northern Provinces) Commission of Inquiry, Laid on the table of the House of Representatives as Sessional Paper No. 1 of 1952 (Lagos: Federal Government Printer, 1952) (hereafter Brooke Commission Report), 9

${ }^{21}$ Lugard, Dual Mandate, 78.

${ }^{22}$ Annual Report, Northern Nigeria, 1901. This manpower shortage would continue due to revenue constraints:

Revenue was almost solely generated from taxes and $75 \%$ of this revenue was expended on administration. 
state formally retained Islamic criminal law in Northern Nigeria was itself an anomaly - across its colonial possessions, the British empire tended to outrightly eliminate precolonial criminal law systems. This is hardly surprising: in no realm was it more crucial for the empire to assert its imperial authority than in the domain of crimes, particularly homicides. The power over life and death has, after all, always been one of the marked prerogatives of the sovereign. Empire's aversion to directly setting aside the Islamic law regulating crimes in Northern Nigerian Islamic law was partly informed by the history of the precolonial caliphate - criminal law was historically the domain in which Sharia was most consistently applied in the precolonial Sokoto Caliphate. ${ }^{23}$ Indeed, when scholars like Schacht and Anderson argued that the colonial state reified Islamic law far beyond its precolonial status, that charge probably stemmed from a mistaken conflation of the history of Islamic criminal law in much of nineteenth century Middle East and North Africa with that of precolonial Northern Nigeria. ${ }^{24}$ In the former, Islamic law was the applicable as family law and other aspects of so-called personal law and as the law of property while the criminal law domain tended to be govern by codes styled after European law and introduced by colonial officials or "modernizing indigenous rulers." 25 The reverse was the case in Northern Nigeria; the Quran, hadith and classical juristic texts formed the go-to source of law in criminal matters while generally, urf, custom, took precedence in governing personal matters and property law. ${ }^{26}$ Under these circumstances, eliminating Islamic criminal law outrightly would have been impolitic for a colonial state resting its legitimacy on the 1903 "guarantee of non-interference."

For all the colonial state's lip service, however, Islamic criminal jurisprudence suffered the fate of abolition in Northern Nigeria as it did elsewhere. In the first place, the state held up Islamic criminal law to a nebulous standard of "natural justice, equity and good conscience."27 Perhaps no

\footnotetext{
${ }^{23}$ See Christelow, Allan. "Islamic law and judicial practice in Nigeria: An historical perspective." Journal of Muslim Minority Affairs22, no. 1 (2002): 185-204.

${ }^{24}$ Christelow p. 188

${ }^{25}$ Id; Christelow, Allen, ed. Thus Ruled Emir Abbas: Selected Casese from the Records of the Emir of Kano's Judicial Council. No. 5. MSU Press, 2012

${ }^{26}$ But the argument is well is that urf was regarded as Islamic law.

${ }^{27}$ The state's haphazard response to determining what violated this nebulous standard was most visible in the domain of punishment: hardly engaging with juristic debates and preexisting legal practice, the state decreed the permissibility of punishments such as drowning, beheading, and outlawing those such as stoning. As opposed to the state's assumption that stoning had been integral to the precolonial caliphal criminal justice infrastructure, stoning had not been in use in the precolonial caliphate. Further, drowning and beheading, the punishments decreed by the
} 
aspect of Islamic jurisprudence relating to crime was more antithetical colonial officials' notions of criminal justice than the institution of diya. Diya's presumption that the individual had authority over the response to a crime directed at or concerning her/him, was anathema to colonial officials' sense of justice and rule of law. With colonial officials insisting that the payment diya challenged the rule of law and ultimately imperial authority and jurists (and emirs) insisting that the institution was central to the administration of criminal justice, the stage was set for a protracted debate over diya. That the colonial state came out ahead in the debate-without recourse to direct compulsionlies in the procedural genius of colonial rule of Islamic law.

Rather than decreeing the abolition of Islamic criminal law, including of diya, as it did elsewhere, the colonial state's abolition of northern Nigerian Islamic criminal jurisprudence took the form of the "constitutional trick" described in Margery Perham's West African Passage. ${ }^{28}$ Perham who was not only an academic authority on colonial administration but also Lugard's protégé and official biographer had an intimate knowledge of the workings of Northern Nigerian colonial administration and immense influence in the Colonial Office. ${ }^{29}$ British indirect rule, argued Perham, entailed the ceremonial bolstering of emirs' powers who then became the vehicle of colonial rule - and colonial legal transformation. The rationale for this design is set out in Lugard's Political Memoranda which became the primary manual of colonial administration. "The emir," argued Lugard, "commands allegiance as the "Head of the Faith" since "the Koran enjoins implicit obedience to his commands." ${ }^{30}$ Springing from this realization, the colonial state invested emirs with exaggerated powers thereby centering executive authority in general became central to the colonial governance of Islamic law. By doing so, the colonial state not only upset the precolonial

state had become very rare but the colonial state's enactment of the punishments would have the effect of rigidifying them. Milner, A. (1972). The Nigerian penal system; Sarah Eltantawi, Shari'ah on Trial: Northern Nigeria's Islamic Revolution. Univ of California Press, 2017., (117-120). Amputations and stoning are rare in precolonial northern Nigeria: Muhammad Sani Umar, Islam and Colonialism: Intellectual Responses of Muslims of Northern Nigeria (Leiden: Brill, 2006), 45. See also Schacht, Introduction and Peters, Crime and Punishment.

${ }^{28}$ Perham, West Africa Passage Id

${ }^{29}$ See Smith, Alison, and Mary Bull, eds. Margery Perham and British Rule in Africa. Vol. 13. Psychology Press, 1991; Robinson, Kenneth. "Margery Perham and the colonial office." The Journal of Imperial and Commonwealth History 19, no. 3 (1991): 185-196; Perham, Margery, ed. The Diaries of Lord Lugard. Faber \& Faber, 1959; Lugard, S.F.D. and Perham, M., 1965. The Dual Mandate in British Tropical Africa... With a New Introduction by Margery Perham. Frank Cass \& Company.

${ }^{30}$ Frederick Lugard, Political Memoranda 
balance between emir's authority and jurists fiqh, but also ruptured the precolonial links between siyasa and the Sharia—as it had been expounded by jurists.

This is not to deny siyasa deviations from the Shari' constitutional boundary in precolonial Sokoto. In fact, if one is to take seriously the manifesto of Shehu Dan Fodio, the leader of the revolt that birthed the Sokoto Caliphate in 1804, a primary motivation of the reform was the restoration of siyasa to its Shari constitutional limits. ${ }^{31}$ Dan Fodio's jihad manifesto ${ }^{32}$ laments the "corruption" of the administration of justice by political authorities. Dan Fodio's musing was hardly an abstract lament; as a jurist himself, he had witnessed first-hand how a leaders' capacious siyasa could stifle juristic expression. ${ }^{33}$ Yet, even the state created in the wake of Dan Fodio's revolution was not free of capacious exercise of siyasa to stifle jurists' fiqh. ${ }^{34}$ Dan Fodio himself wistfully laments such abuses by political authorities, including executive officials in charge of provinces in his famous poem, Wallahi Wallahi. Yet, as scholars have pointed out, siyasa deviations from the Shari' constitutional boundary-as expounded by jurists' fiqh-were not the norm. ${ }^{35}$ Describing the constitutional structure of the caliphate, Murray Last argues that the Sharia was regarded as "the source of authority," binding the Caliph's siyasa powers. ${ }^{36}$ Moreover, the Caliphate's legitimacy was understood as hinging on a "universal law," giving the caliphate the authority it lacked in military might. To be sure, this universal Sharia was not conflated with jurists' fiqh - it was also popularly acknowledged that the totality of the sharia was incomprehensible to man since it was God's law. This translated into the recognition that no individual jurist could completely

\footnotetext{
${ }^{31}$ Murray Last; Mervyn Hiskett; R. A. Adeleye: The Overthrow of the Sokoto Caliphate 1879-1903 (Ph.D. Thesis, Ibadan, 1967), Ch. I.

${ }^{32}$ Tabbat Hakika

${ }^{33}$ Levtzion, Nehemia. "Islam in West African Politics: Accommodation and Tension between the'ulamā'and the Political Authorities (Islam et politique en Afrique occidentale: compromis et tensions entre les ulémas et l'autorité politique)." Cahiers d'études africaines (1978): 333-345. Other examples from across west africa

${ }^{34}$ See Murray Lastfor examples of such, narrated in the light of political corruption in the caliphate.

${ }^{35}$ For the constitutional arrangement of the precolonial Sokoto caliphate (and of the kanem bornu empire), see J. S Trimingham, A History of Islam in West Africa; Ajetunmobi, Musa Ali. Shariah Legal Practice in Nigeria 1956-1983. Kwara State University Press, 2018, 24-30; A. Adeleye: The Overthrow of the Sokoto Caliphate 1879-1903 (Ph.D. Thesis, Ibadan, 1967); Adeleye, The Dilema of the Vizier Journal of Historical Society of Nigeria, p. 285-7 See further I.A.B Balogun, The Life and Works of Uthman Dan Fodio; Murray Last; Mervyn Hiskett

${ }^{36}$ See Last, p.232 Last. See also Ajetunmobi, Id; Balogun, Ismail AB. The Life and Works of 'Uthmān Dan Fodio: The Muslim Reformer of West Africa. Islamic Publications Bureau, 1975. A Adeleye, "The Dilemma of the Waziri", in Power and Diplomacy in Northern Nigeria 1804-1806: The Sokoto Caliphate and its Enemies, London, Longman Group Ltd., 1971. See further D. J. Fuffet: Concerning Brave Captains (London, 1964) (refuting claims that there was so much corruption that the Sokoto caliphate had lost Islamic character.)
} 
apprehend the Shari'a; yet it was understood that it was in the work of jurists as a whole that the effort to discern the law could be undertaken. Surviving material preserving caliphal practice therefore reflects jurist-expounded Shari' constraints on siyasa—even when constitutional practice sometimes violated this norm.

The colonial state freed emirs siyasa powers from pre-colonial constitutional constraints. In drawing on their newfound expansive siyasa to curtail jurists' fiqh, emirs cited hukm zamana ("the rule of our era") that is the exigencies of colonial rule as mandating their decisions. At the same time, however, emirs legitimated this colonial-era siyasa by invoking the Sharia as the basis for their political authority. They argued, in essence, that the siyasa could transgress its Shari limits in response to the realities of colonial modernity while being simultaneously legitimated by the sharia. The result was that colonial governance of Islamic law did not merely upset the siyasa-fiqh constitutional balance, it also transformed the discursive terms of the debate. The exercise of political authority to transform the law became legitimate not because it complied with Shari' limits a priori but rather because it was siyasa as such. Siyasa, consequently, came to legitimate the Sharia, deviating from the historical ideal of the Sharia serving as the test of siyasa's legitimacy.

If this transformation was astonishing, what followed was even more startling. As ideological currents on imperial rule changed among the upper echelons of the colonial administration, the colonial state resorted to carrying out its project, first through colonial officials-the middle-aged administrators described in Margery Perham's West African Passage-and ultimately through the executive and legislative institutions of the late colonial state. When this turn to direct reform was met by revolt of emirs and jurists, the state only dug in its heels. What was however striking was that this direct reform continued to latch on to the design of indirect rule. The reform was legitimated not as the exercise of power by the imperial sovereign that it was but rather as a legitimate exercise of siyasa. In this way, the colonial state, in its early and late formation, could claim continued fidelity to Islamic law and caliphal institutions, including, for the purpose of this article, the institution of diya, while simultaneously altering its principles.

\section{Debating Diya}


As the doctrine governing the payment of compensation for what may be loosely described as unlawful killing, diya falls under the qisas branch of Islamic criminal law's three categories. Qisas, retribution laws, regulates response to killings (intentional and unintentional) and bodily injuries. ${ }^{37}$ Besides Qisas, the other two categories of crimes are hudud-those offences that infringe on the rights of God and the third, ta'azir, discretionary punishments prescribed by the ruler, ideally for the purpose of maslaha, "public interest." The boundaries between these three categories have not always been firm; as an exercise of the state's discretion and justifiable as siyasa, the realm of ta'azir has sometimes encroached into the spheres of hudud and qisas. With regards to diya, the debate over the blurring of boundaries between ta'azir and other categories of crimes particularly qisas, has centered on whether the payment of diya marks the conclusion of a case. While scholars agree that diya vests the right to mitigate punishment ${ }^{38}$ in the aqillah "the relatives" of the victim, ${ }^{39}$ there is no consensus over whether diya obviates further punishment. The Maliki and Hanafi position is that the state may also impose ta'azir as a discretionary punishment in addition to the payment of diya (if it is in the "public interest" (maslaha) to do so. ${ }^{40}$ In such cases, however, the punishment would be less than the death penalty. Along these lines, jurists in precolonial Nigeria drew on classical Maliki doctrine to argue that the emir had discretion to impose a taazir punishment in addition to diya and afw. ${ }^{41}$ That punishment prescribed in the classical texts was one year imprisonment and 100 lashes delivered as to avoid bodily injury; some jurists, however, debated whether the emir further had the discretion to increase the taazir punishment in the interest of public order. ${ }^{42}$ Although Maliki doctrine was favored, jurists did not consider themselves constrained by this school of jurisprudence and its prescription of additional punishment after the

\footnotetext{
${ }^{37}$ While diya is compensation payable upon unlawful killings, arsh is payable for bodily injuries. See Kamali Id, p. 221,

${ }^{38}$ Classically, this was concerned with cases of intentional killing; for where the killing was unintentional or involved an element of fault or negligence but does not rise to the degree of intentionality, diya (or a ta'azir punishment) is the remedy, rather than a qisas retaliation, regardless of the wishes of the relatives of the victim.

39 Technically "aqillah" (agnatic group). The examples in this article focus on this meaning as this was the understanding prevalent in Northern Nigerian juristic discourse although I recognize that there is debate over whether the aqillah ought to be extended beyond the agnatic group. For instance, it has been claimed that in the earliest of caliphates, in the time of Caliph Umar ibn Khattab, aqillah included colleagues in the offenders workplace ((ahl al- dīwān)) leading to the contemporary argument (by Yusuf Qaradawi) that Aqillah may include professional associations. See Kamali Id, P. 214; 217

${ }^{40}$ Kamali Id, 215

${ }^{41}$ Northern Nigerian jurists drew widely from classical Maliki texts. Beyond Imam Malik's primary work, Al- Muwatta and the second major Maliki text (Ibn Qasim's Al-Mudawwana), records indicate the jurists often cited Ibn Abi Zayd's Risālah, Khalil ibn Ishaq al-Jundi's Mukhtasar (Khalil) and Al-Mudawwana (Ibn Qasim). Jurists also drew from a long line of commentaries on these and other texts.

${ }^{42}$ Anderson Conflict of Laws article. p. 448
} 
payment of diya. In fact, the juristic license to engage in takhayyur (drawing from the juristic thought in different schools of jurisprudence to rule on different questions) and talfiq (choosing elements of opinions across different schools of thought) was granted by no less than the founder of the precolonial caliphate, Uthman Dan Fodio in his magnum Ihya' as-Sunnah wa Ikhmad aBid'ah. ${ }^{43}$ To that extent, the Shafi and Hanbali position that diya mitigates punishment completely was therefore also authoritative in shaping in precolonial juristic thought and practice on diya.

In some ways, the debate over whether diya completely obviates punishment tracks the discussion over whether diya amounts to afw (pardon)-or whether it is a form of punishment in itself separate from and that may coexist with afw. Consistent with their view that diya is exculpatory, Shafites and Hanbalites opine that the grant of afw relieves the qisas convict from punishment-although afw may or may not be followed by diya. In that view, therefore, afw though separate from diya, may, in fact, coexist with it. ${ }^{44}$ The Hanafi school, however, regards afw as absolving the qisas convict without the payment of any compensation; afw consequently does not co-exist with diya in that school of thought. ${ }^{45}$ Yet, as mentioned above, the Hanafi position, as the Maliki, envisage that the political authority may impose a ta'azir punishment regardless of whether the victim's relatives granted afw, a pardon, to the convict and/ or whether they sought diya, monetary compensation for the killing. Regardless of these nuanced debates, precolonial jurists expressed unwavering consensus that diya (and afw) was available to victims' agnates as an option to preclude the death penalty in cases of intentional killing and as an option to preclude a lesser penalty in cases of unintentional or culpable homicide. The variation was in their response to the question whether political authorities could invoke siyasa powers to impose ta'azir punishment in addition to diya or afw. This was the state of legal discourse and judicial practice before Colonel

\footnotetext{
43 Ihya' as-Sunnah wa Ikhmad a-Bid'ah. See Ajetunmobi, Musa Ali. Shariah Legal Practice in Nigeria 1956-1983. Kwara State University Press, 2018, p. 27 See further I.A.B Balogun, The Life and Works of Uthman Dan Fodio. See further, Anderson Conflict of Laws article. p. 448

${ }^{44}$ Kamali 215

${ }^{45}$ This position therefore seems to espouse the view that diyah is punitive For contemporary assertions that diya is solely as a punitive measure, a form of deterrence for future crimes. Ghaouti Benmelha, Ta'azir Crimes, in The Islamic Criminal Justice System 224 (Mahmoud C. Bassiouni ed., 1982); Bassiouni, supra note 43, at 206; Gottesman, supra note 34, at 447; Gunnar J. Weimann, Judicial Practice in Islamic Criminal Law in Nigeria, 14 Islamic L. \& Soc'y 240, 254 (2007) At the same time, however, another contemporary position espouses the view that diya incorporates forgiveness and is more properly, regarded as a restitution [and a restorative response] rather than a punitive one. M.J.L Hardy, Blood Feuds and the Payment of Blood Money in the Middle East 46 (1963
} 
Frederick Lugard formally pronounced Northern Nigeria a British Protectorate on the morning of March 15, 1903.

Colonial administrators took a dim view of diya as a doctrine governing criminal law. Officials found it peculiar that diya simultaneously featured elements of both a criminal and civil action. By granting victims' agnates the right to mitigate punishment, diya essentially moved a crime from the domain of the state-which administrators considered as having the sole prerogative over crimes-to that of individuals. ${ }^{46}$ This exercise of individual authority in the domain of crimes was unacceptable to English administrators. Not even those administrators with the most ardent fascination for emirate institutions-Frederick Lugard, and those administrators sharing his orientalist approach to Northern Nigeria-could reconcile diya with the premises of imperial authority. The debate over diya was therefore at its core a debate over whether it was the colonial state had the sole prerogative to determine response to crimes, or whether affected individuals had jurisdiction to determine the fate of the convict. For Northern Nigerian jurists, the response was clear, diya had an unequivocal basis in the source texts and a long history of being enforced and was therefore an unnegotiable aspect of criminal law. Colonial administrators insisted, however, that interpersonal resolution of crimes challenged the colonial state's sovereign authority and the idea that the state was the unquestioned agent of justice. ${ }^{47}$

Beyond this desire to establish the empire's ultimate authority of life and death and punishment, the colonial aversion to diya and afw as a mode of settling disputes over homicides also sprung from administrators' concern with criticism certain to emerge from British judges in the colony, Christian missionaries and natives trained in English law, the overwhelming majority of whom were non-Muslim in the colonial years. ${ }^{48}$ In fact, the application of diya in cases involving nonMuslims only heightened the institution's unpopularity within the colonial administration. In the

\footnotetext{
${ }^{46}$ But see article on common law history of crimes as granting individuals authority

${ }^{47}$ Allan Christelow, Persistence and Transformation in the Politics of Shari'a, Nigeria, 1947 2003: In Search of an Explanatory Framework in "Muslim Family Law in Sub-Saharan Africa. Colonial Legacies and Post-colonial Challenges Edited by SHAMIL JEPPIE, EBRAHIM MOOSA and RICHARD ROBERTS," Lugard, Lord Frederick JD. The dual mandate in British tropical Africa. Routledge, 2013.

${ }^{48}$ Christelow, persistence and Transformation, Id, Rabiat Akande, Neutralizing Secularism (forthcoming); Adewoye, Omoniyi. The judicial system in Southern Nigeria, 1854-1954: law and justice in a dependency. London: Longman, 1977.
} 
first place, certain non-Muslim customs prohibited the acceptance of diya. Colonial records for instance record a case with unnamed parties in which the agnates of an animist victim declined the payment of diya for a killing that could not be established to be an intentional homicide. ${ }^{49}$ Given the absence of proof of intentionality and with the agnates refusal of diya payment, the qisas convict walked free. Such cases heightened criticism of diya within the ranks of the colonial administration. For all this criticism, however, outright abolition of diya was not a feasible option given the design of Lugardian indirect rule. An appropriate response to the problem therefore called for the genius of indirect rule - effecting the change through emirs' authority now bolstered by colonial might.

In its classic form, the elimination of diya took the form of issuing "instructions" to emirs. Instructions were a standard mechanism of indirect rule. "The system of native administration," Lugard stressed, was "based on a recognition of the authority of the Native Chiefs. The policy ... was that these chiefs should govern their people, not as independent but as dependent Rulers. The orders of Government are not conveyed to the people through them but emanate from them in accordance ... with instructions received through the Resident." ${ }^{50}$ Communicated orally as suggestions in meetings, "instructions" were designed to ease the discomfort of emirs and alkalai with colonial overrule and crucially, to maintain the legitimacy of the emirate institutions before the general population. As John Carrow, a colonial administrator put it in when issuing one of such "instructions" to the emir of kano, such a benign mechanism would "avoid gossip and intrigue," which may threaten the basis of colonial governance. ${ }^{51}$ The Lugardian design was built on the expectation that emirs would deploy their siyasa powers carry out these instructions. Although emirs exercised siyasa powers over ta'azir punishments in pre-colonial years, colonial era reforms went beyond the confines of pre-colonial juristic discourse on the Shari' limits of ta'azir jurisdiction. In response to alkalai resistance, emirs would then argue that siyasa's departure from juristic understandings on diya was legitimate since siyasa powers itself derived from the primary source of law-the Quran. In one of the better-known confrontations between an alkali

\footnotetext{
${ }^{49}$ See J.N.D. Anderson, The Reform of Criminal Law Introduced by the British, File 365205 PPMS 60/1/12-17, SOAS Library Special Collections, London.

${ }^{50}$ Emphasis supplied [check Dual Mandate]

${ }^{51}$ Rights of Non Mohammedans Before Mohammedan Courts" File np 16032, Arewa House Kaduna in MS Umar, Islam and Colonialism, 48
} 
and an emir, the alkali refused to comply with the Emir's directive on the basis that he "could not enforce a law made by an emir that is not in the Quran." The Emir, however insisted that his directive was a legitimate exercise of siyasa, declaring that "Islamic law strictly commands obedience to those in authority," and overruled the alkali. ${ }^{52}$ In this way, emirs invoked siyasa to legitimate the ruling as Sharia.

This deployment of siyasa authority to legitimate administrators instructions was sanctioned by the foremost surviving (remaining) caliphate official at the commencement of colonial occupation and noted jurist, Waziri Bukhari. Grappling with the dilemma of subjugation at the dawn of colonial conquest in his Risala Al-Wazir'ila al Ilm Wa'l Tadabbur, Waziri Bukhari advocated taqiyyah: "befriending" the colonizers "with the tongue but not the heart." ${ }^{53}$ Bukhari's successor, Waziri Jinadu, provides an insight into this preference of taqiyya in his address to a scholar criticizing the Sultan's practice of praising the King of England after Eid prayers. Jinadu, who was at the time, the leading judicial figure in Northern Nigeria stressed: 'this is a time for silence and keeping at home. Whoever speaks the truth would die." 54 For Bukhari as Jinadu, therefore, ostensible cooperation with colonizers was the price for the primary goal of preserving caliphal institutions.

Nevertheless, diya and afw were regarded as so central to the criminal justice system that invoking taqiyyah to set effectuate colonial directives to set them aside was a delicate matter. Emirs were therefore known to explicitly cite colonial instructions as the basis for directing alkalai to depart from precolonial juristic practice on diya (and afw). In Katsina NA v. Yakudi of Hababa and Dankoko of Renage $e^{55}$ for instance, the Emir cited "the instruction of the government" in quashing the Chief Alkali's decision discharging a homicide convict who had been granted afw by the victim's family. Effectively disregarding the agnates' pardon, the Emir then sentenced the convict to death. ${ }^{56}$ The Emir's explicit invocation of the resident's instruction was intended to secure legitimacy for the decision. By citing government instruction as the basis for a decision

\footnotetext{
52 Anderson, "A Survey of Islamic Law in Nigeria."

${ }^{53}$ Risala Al-Wazir'ila al Ilm Wa'l Tadabbur . also Adeleye, dilemma of the waziri, 298

${ }^{54}$ Gumi, Abubakar Mahmud, and Ismaila Abubakar Tsiga. "Where I stand." (1992) p. 51. See also 187-8 Christelow, Allan. "Islamic law and judicial practice in Nigeria p. 43

55 John Anderson, "A Survey of Islamic Law in Nigeria" PPMS 60/1/12-17 SOAS Library Special Collections, London.

${ }^{56}$ Anderson, "A Survey of Islamic Law in Nigeria."
} 
unsupported by jurisprudence or precolonial practice, the emir argued that he was constrained by the demands of imperial overlordship. Such a decision, the emir argued-as did several other political elites and alkalai-was authorized not by jurisprudence but as hukm zamana "the rule of our era." The legitimacy of hukm zamana did not however lie in the threat of force per se although that was not completely absent from the background possibilities. Rather, hukm zamana was legitimated by its expression through the emirs siyasa, a siyasa that was always asserted to be consonant with the Sharia even when it transgressed juristic expositions Sharia's constitutional boundaries.

This siyasa-fiqh tussle over criminal punishment extended beyond diya; jurists challenged what they viewed as the colonial state's overreach in the resolution of crimes far beyond the ta'azir jurisdiction of precolonial years. A leading figure of this juristic resistance, Waziri Gidado, the highest-ranking judge in the Kano emirate from the first decade of colonialism until his passing in 1937 argued that only offences involving public safety or security such as highway robbery ought to involve political authorities. otherwise, Gidado argued, the victim had jurisdiction to determine the response to the crime. As a mark of this resistance to state involvement, a number of akalai staunchly refused to permit the police to conduct formal prosecution of crimes before their courts even in defiance of emirs' orders. ${ }^{57}$ Rather than institute formal prosecutions as they did in Magistrate Courts and High Courts, police officers could only be called as a witness by the prosecution. ${ }^{58}$ These alkalai stressed, instead, the control of the parties involved over the process through the means of oaths as well as the testimony of witnesses, which may incidentally include the police. In cases of (lawth), circumstantial evidence, many akalai insisted not on police investigation as colonial administrators sought, but rather on an oath by the agnatic affiliates of the victim (qasama). Alkalai also refused to enforce government ordinances, rendering ineffectual an alternative route to enforce compliance.$^{59}$ Regardless of these pockets of resistance to colonial attempts to overhaul criminal justice and eliminate diya and afw, inclination towards the taqiyyah prescribed by Bukhari's seems to have prevailed. This situation was due, in no small part, to the

\footnotetext{
${ }^{57}$ See Christelow, Persistence and Transformation 24-5

${ }^{58}$ Christelow Persistence and Transformation in edited volume) See Report of the Judicial Advisers' Conferences held in 1953 at Makerere College, Uganda. (records published as Special Supplements to the Journal of African Administration in October 1953) p. 35

${ }^{59}$ See Resident Kano to D. O. Hadejia, 14 December 1937, in National Archives, Kaduna, KANOPROF 2182
} 
legitimacy of emir-intermediaries. Emirs' deployment of siyasa to effectuate colonial directives in the first decades of colonial rule made taqiyyah an easier pill to swallow however expansive the colonial-era siyasa had become.

Widespread resistance to the colonial project, however, began to intensify in the 1930s. Mounted by jurists, alkalai and emirs, this resistance was in response to changing ideas on the place of caliphate institutions in the colonial governance project. Specifically, Lugardian reticence to bypass emirs and proclivity towards expanding emirs' siyasa powers as a tool of rule came under attack, both from a new breed of administrators in Northern Nigeria as well as from the upper ranks of the Colonial Office in London. Championed by Governor-General Donald Cameron, the new breed of administrators sought the making of a colony in which men are given the opportunity to grow to their full stature" - on the foundation of "Christianity and the rule of law." Lugardian model of ostensible deference, including in the realm of what was regarded as the strange institution of diya, was inconsistent with this goal. Faced with the shedding of the veneer of orientalist fascination, emirs began to tentatively join jurists and alkalai in expressing resistance to the colonial project. In 1930, the Advisory Council of Emirs passed a resolution that "they were unable to suggest any departure from the strict letter of Mohammedan law" on the basis that, if they did so, "all their subjects ... would feel that they had abandoned their religion." 61

Rather than back down, the colonial state began to effect its reform policies directly through colonial administrators' supervisory jurisdiction. Although this vehicle had existed since the Lugardian years as an alternative in cases where emirs resisted, it was in the non-deferential posture of Cameron-era administrators that it found its true expression. In the Hassana of Fura case for instance, Hassana was convicted of murdering her former husband's new wife by poison. The victim's relatives then exercised their right of afw whereupon the Emir discharged the convict ignoring the Residents' instruction. The Resident, however insisted that a punishment of death ought to be imposed, recommending that the regional governor overturn the Emir's court's

\footnotetext{
${ }^{60}$ See Todd Thompson, Norman Anderson and the Christian Mission to Modernize Islam (Oxford: Oxford University Press, 2018), p. 163. See "On this day: 3 february - 1960: Macmillan speaks of 'wind of change' in Africa" BBC.co.uk Retrieved July 15, 2021, Cameron, Donald. "Native administration in Tanganyika and Nigeria." Journal of the Royal African Society 36, no. 145 (1937): 3-29.

${ }^{61}$ Report of the Native Courts (Northern Provinces) Commission of Inquiry Laid on the table of the House of Representatives as Sessional Paper No. 1 of 1952 (Lagos, Federal Government Printer, 1952), (hereafter Brooke Commission Report) p. 184
} 
decision. Although the governor retained the reticence of the Lugardian years and hesitated to overturn the emir, the demands of the new colonial policy required him to do so. The regional governor therefore imposed a judgment of 5 years imprisonment. ${ }^{62}$

As the Hassana of Fura decision shows, the phasing out of diya in a departure from pre-colonial practice did not always result in the imposition of capital penalty. In fact, administrators tended to consider whether the facts presented a mitigating factor that ought to lessen the charge from one of murder to manslaughter under English Common Law. If one existed, such as the common law defence of provocation, administrators sometimes commuted the sentence as the Governor did in the Hassana of Fura case. Although this channel prevented the execution of the capital penalty as the precolonial practice on diya did, the colonial mechanism was criticized for taking the decision out of the hands of the victim's agnates-Muslim jurists insisted, "the right of mitigation was vested in the holder of the blood right." ${ }^{93}$ In the Burutu case, for instance, the defendant had killed the victim in the course of a fight and argued that the fight was triggered by the presence of the victim, a "notorious thief," on his property with what he was certain was an "intent to steal". The jurists on the Emir of Kano's court cited the risala and Khalil's mukhtasar to hold that the right to mitigate only inheres in agnates of the victim; ${ }^{64}$ in the absence of such agnates the emir only had the right to exercise his ta' azir power of retaliation and could not mitigate the convict's punishment by offering the alternative of diya ${ }^{65}$ In the same vein, even in cases where agnates insisted on retaliation but administrators found mitigating circumstances, the capital sentence pronounced by the emir/ alkalai court could be commuted. This power to commute was typically exercised by the Resident, either directly, or by the Governor, on the Resident's recommendation. As M.S Umar

\footnotetext{
${ }^{62}$ Brooke Commission Report, p. 128

${ }^{63}$ See for instance the Burutu Case. Kano N.A v. Ahmadu of Burutu 1938 KANO PROf. File 2874 NATIONAL ARCHIVES, KADUNA

${ }^{64}$ Curiously, the jurists on the emir of kano's court construed agnates in this case to only refer to men. Therefore, although a female agnate was present and expressed a demand for diya, the court declined to consider her wishes. See footnote [73] below

${ }^{65}$ See similarly also Machido case in which the three defendants, were convicted for killing of the victim in the course of a brawl between several members of their family and the victim's family. The Resident exercised the power to commute. Kano N.A v. Machido Dan Bakar Bibu and Dubo Dan Yammza and Dambatta 1936 in KANO PROF. FILE 1808. See for instance the commutation of the capital sentence handed out to a qisas convict, Ciroma Mai Kano, to life imprisonment on July 7, 1942. Kano NA v. Ciroma Mai Kano. Kano Prof. File 4867 Kaduna National Archives
} 
puts it, the resident exercised the ultimate "veto power over life and death." ${ }^{66}$ Residents commonly cited provocation as a mitigating factor in commuting sentences. In the Dan Iya Bogwe case, the defendant claimed that he found the victim stealing on his farm whereupon he flung a hoe at the victim, killing him. The victim's family insisted on the capital penalty for Dan Bogwe and took the lawth, the fifty-fold oath testifying that the defendant's act had resulted in the victim's death. Giving effect to the agnates' wish, the alkalai pronounced the capital penalty. Regarding the facts of the case as extenuating, the Governor substituted the capital penalty for imprisonment for five years ${ }^{67}$ Similarly, the capital penalty in the Burutu case was overturned on appeal as the court regarded the facts as indicative of mitigating circumstances. ${ }^{68}$

The result of these reform efforts was that diya would become so obliterated that as early as 1933, the Chief Commissioner of Kaduna would declare: "no murderer escapes punishment because the blood relations have claimed diyya ... our influence over a course of years has resulted in criminal law in Native Courts in all important matters coming into accord with our [English] criminal law to the extent that there cannot be said any longer to exist (in practice) a separate and distinct Mohammadan Criminal law." ${ }^{69}$ While declaring the de facto elimination of diya (and Islamic criminal jurisprudence) however, the Chief Commissioner pointed out that the formal procedure of the court was to still put the question to the victim's agnates whether they would prefer diya over punishment. In the early Cameron years, therefore, the formal procedure affirmed the existence of diya in theory although diya was, in practice, inexistent. In this way, the state could

\footnotetext{
${ }^{66}$ Umar, Muhammad S. "Hausa Traditional Political Culture, Islam, and Democracy: Historical Perspectives on Three Political Traditions." In Democracy and Prebendalism in Nigeria, pp. 177-200. Palgrave Macmillan, New York, 2013, p. 187

${ }^{67}$ A similar approach was adopted in Kano N.A $v$ Isau Bansaki in which the criminal defendant killed the victim on the basis that the latter seduced his (traveling) son's wife. Kano Prof. File 2157. Wife seduction cases accounted for a large number of 'provoked' murders.

${ }^{68}$ It is paradoxical that in referring the case to the High Court, the colonial administrators argued that the emir of kano's court committed an "error of law" under Maliki jurisprudence in denying female agnate the right to retaliate or mitigate. The High Court then proceeded to substitute the death penalty for a sentence of imprisonment for 1 year and 100 lashes; the court further remarked that it was leaving the question of diya to the alkalin kano to settle. It therefore appears that despite the colonial administrators' hostile posture to the institution of diya, colonial administrators sometimes allowed the payment of diya to pacify agnates where the state overturned the death penalty for killings amounting to homicide under Islamic law on the basis that the facts presented mitigating circumstances in common law.

69 July 4, 1933. No 1145/105 Abdulmalik Bappa. "A brief history of Shari'ah in the defunct Northern Nigeria, p. 21. See full version of letter in Anderson, Islamic law in Africa, p. 199
} 
continue to pay lip service to the guarantee of non-interference in Islam and deflect criticism, while effecting substantive reforms in practice.

The strategy of cautious reform, influential in the 1930s, began to wane as Cameron ideology attained increasing popularity in the colonial administration. The tension between these directreform-minded administrators and Muslim political and legal elites climaxed in Guba v. Gwandu NA. In that case, the West African Court of Appeal (WACA) set aside the decision of an alkalai court delivered according to Islamic law solely on the ground of its non-compliance with English Common Law and the Criminal Code, a colonial legislation that had hitherto only applied to nonMuslims appearing in English courts. ${ }^{70}$ The WACA pronouncement, held, in essence, that alkalai had to comply with English Common Law and colonial statutes in deciding cases. Although the Guba decision did not have a direct bearing on the question of diya, it led to an open confrontation that had far reaching consequences for the settlement on diya. In response to the shift to overt reform which would eventually culminate in the Guba decision, three prominent Sheikhs of Kano Law School, the institution responsible for training colonial-era alkalai, prescribed a reversal of the ostensible cooperative approach to colonial state recommended by Waziri Bukhari in 1903. Rather than taqiyyah, the kano law school sheikhs ordered outright dissociation from the colonial project:

"The Shari'a is all sufficient and unchangeable. If after diligent search, no written guidance is found, judgment may be given in the spirit of the Law, but where the Quran prescribes a judgment, no other may be given... Nevertheless, where for one cause or another, the whole government is not to be bounded by the Scriptures, it is better that those judges whose authority is founded upon the Shari'a should touch nothing in which the Shari'a may not be fulfilled. In Nigeria today, the alkalai profess that their authority is from the Shari'a, yet in many of their judgments they may not in certain matters which are brought before them pronounce the judgments prescribed by the Qur'an ..."”1

Tensions only heightened in the aftermath of this pronouncement, and eventually emirs and alkalai began to refuse to exercise jurisdiction over cases. Reform minded administrators were unwilling

\footnotetext{
70 Tsofo Gubba v. Gwandu Native Authority (1947) WACA, vol. 12.

${ }^{71}$ Memorandum by Annur Tingary, Bashir El Rayah, and Mohammed Swar El Dahab "Extension of Jurisdiction of Native Courts" KANO PROF File \#2182, pp. 41-43 in Gloster, “The Evolution of Maliki Law in Northern Nigeria," 40.
} 
to relent; yet, these, as the earlier Lugardians, acknowledged the need to secure compliance of the Muslim elites by means other than force. Although the threat of force always remained in the background, administrators opined that the use of force especially against the vehicles of rule ought to be a last resort. ${ }^{72}$ This disinclination from the exercise of force was not due to humanitarian considerations; it stemmed instead from the understanding that the use of force detracted from the legitimacy of empire and ultimately from the authority of the colonial state. To legitimize the reform efforts, colonial administrators began to justify their exercise of power over and in particular, the preclusion of diya and afw, as a legitimate exercise of siyasa. The origin of this discourse lies in the work of JND Anderson, Professor of Oriental laws at the School of Oriental and African Studies and foremost western twentieth-century expert on Islamic law.

\section{Statizing Siyasa; Eliminating Diya}

JND Anderson's attraction to the Colonial Office sprung from the scholar's reputation as an Islamic legal expert with a "love-hate relationship with Islamic law." "73 A firm believer in Henry Maine's thesis that legal systems evolve with societies' stage of development, Anderson marked the institution of diya to Northern Nigeria's primitive stage. Yet, Anderson insisted that Northern Nigeria's evolutionary process had to be helped along for a number of reasons. In particular, Anderson pointed out that Northern Nigeria's mixed religious population was incompatible with diya given disparities in compensation along the lines of religion and gender. ${ }^{74}$ Prominently, Anderson cited the view, based on classical Maliki thought, that non-Muslims had to be content with receiving diya and could not demand retaliation for a murder. What Anderson's study missed was however that Northern Nigerian judicial practice did not effectuate this juristic position, which historically emerged from a context in which religion was the marker of political belonging and in which religious difference carried a presumption of political dissent. As the qisas case cited earlier,

\footnotetext{
72 The colonial state did not, however, exercise this restraint on the use of force when it came to minorities, See Adeleye, R. A. "Mahdist triumph and British revenge in northern Nigeria: Satiru 1906." Journal of the Historical Society of Nigeria (1972): 193-214, Rabiat Akande, Navigating Entanglements (May 2019) (unpublished S.J.D. dissertation, Harvard Law School).

${ }^{73}$ Richardson, Sam Scruton. No Weariness: The Memoir of a Generalist in Public Services in Four Continents. Malt House, 2001, 217

74 J.N.D Anderson, "Homicide in Islamic Law." Bulletin of the School of Oriental and African Studies 13, no. 4 (1951): 811-828. 811-812; JND Anderson, "Islamic Law in African Colonies," Corona, The Journal of His Majesty's Colonial Service 3 (1951): 265; Anderson, J. N. D. "Conflict of laws in Northern Nigeria: A new start." International \& Comparative Law Quarterly 8, no. 3 (1959): 442-456.
} 
however, shows, non-muslims could in theory seek retaliation even before the colonial state's reforms; nevertheless, practical evidentiary reasons or those pertaining to procedure in general (such as in that case, the slaughtering of sheep) could operate to frustrate the trial and conviction of a Muslim accused of a homicide involving non-Muslims.

Anderson further argued that the doctrine of diya resulted in inequality since the diya due for the murder of a non-Muslim was lower than that payable upon the unlawful killing of a Muslim: for animists, it was limited to one-fifteenth of the sum payable upon the killing of a Muslim and for Christians, this sum was limited to half. This disparity, Anderson argued, also played out along the lines of gender difference among Muslims: a woman's unlawful killing giving rise to only half the diya payable for men. These disparities found expression in the jurisprudence and precolonial judicial practice as a measure of political status and life expectancy; yet, the basis of these disparities in the primary sources-Quran and Sunnah-have been challenged. ${ }^{75}$ In any event, Anderson's criticism of diya was trite given its de facto elimination by the colonial state. In failing to question the state's insistence on its fidelity to precolonial institutions, however, Anderson failed to discern the state's governance of Islamic legal practice. ${ }^{76}$ Proceeding on the basis of this imprecise study, Anderson argued that the institution of diya and of Islamic criminal law in general was unbecoming of a state in the twentieth century, especially one on the cusp of decolonization and becoming an independent member of the international community of states. "No realist," Anderson stated, "would maintain that the Shari'a provides any adequate basis for criminal law in a modern state of mixed religious loyalties and progressive intentions." 77 Anderson therefore argued that unequivocal reform was necessary and insisted that neither the old emirs siyasa expansion mode nor colonial administrators' ad hoc interventions sufficed.

To replace the old channels of colonial reform, Anderson suggested the adoption of a code of criminal law expressly precluding diya along the lines of those in "modern muslim states" like the

\footnotetext{
${ }^{75}$ See Kamali, Mohammad Hashim. Crime and punishment in Islamic law: A fresh interpretation. Oxford University Press, 2019. P. 215 (citing the absence of the disparity in the primary source texts and the positions of Imam Ghazali and his commentator, Yusuf al Qaradawi, as well as modern ijtihad to argue that blood compensation is equal across gender and religious lines).

${ }^{76}$ Anderson also erroneously argued that the inequalities pf diya had only been mitigated by colonial administrators' exercise of discretion to transfer cases involving non Muslims to English courts.

${ }^{77}$ Anderson letter to NJ Brooke April 6, 1951 in Thompson, Norman Anderson, 168
} 
Sudan. The Sudan Penal Code and the Indian Penal Code from which it derived were imperial legislations based on English Law and North American Statutes. ${ }^{78}$ Yet, Anderson argued that the codes could be legitimated by Islamic law to secure the assent of emirs and alkalai. This legitimation of the codification project, as Anderson conceived of it, was to be through the vehicle of siyasa.

As Anderson noted in a 1957 advisory setting out the blueprint for the colonial office, the genius of the reform design he produced lay in its procedural nature. Rather than directly altering the substantive principles of the Sharia, as expounded upon by jurists, modern states like Sudan instead vested in a "Ruler or Legislature the right to confine and define the jurisdiction of the courts" and to determine the substance of the law. The substance of the law therefore hardly mattered once the state invoked its siyasa jurisdiction to legislate. As Anderson put it: "the difference therefore between the way in which criminal justice is administered in Northern Nigeria and other Muslim countries," "is not so much a matter of fundamental principle as of the way in which the siyasa jurisdiction of the state is exercised." 79 Regardless of the western imperial roots of the Sudan code proposed as a model for Northern Nigeria, Anderson therefore insisted that it was a legitimate exercise of the state's siyasa jurisdiction to legislate in the interest of public order. The Code was, in essence, simultaneously imperial and Islamic. In sum, Anderson advised the Colonial Office that the path forward lay in the transfer of siyasa powers from intractable emirs to this new legislature, now controlled by the colonial state.

Anderson's proposal was warmly received at the Colonial Office. To forestall mounting Masu Sarauta opposition, the Colonial Office was however careful to include Muslim jurists on the Panel convened to deliberate on Anderson's reform blueprint Prominently, Syed Abu Rannat, Chief Justice of the Sudan and a Muslim jurist with a reputation as a liberal reformer was appointed chairperson of the panel. Likewise, former Justice of the Pakistani Supreme Court, Mohammad Al Sharif, was nominated to the panel. To further legitimate the panel's work, Northern Nigerian jurists such as Sheikh Musa Othman, the Chief Alkali of Bida, and Shettima Kashim the Waziri

\footnotetext{
${ }^{78}$ Particularly the Louisiana Civil Code and the New York Code Mawani, and Hussin, "The Travels of Law," 741.

79 "Draft Confidential Dispatch to the Governor Northern region, Nigeria, for Clearance SECRET AND PERSONAL by the Governor Before Issue," August 1957, London Private Collection of lan Edge, Anderson papers cited in Thompson, Norman Anderson, 180.
} 
(Vizier) of Borno were appointed. ${ }^{80}$ As the author of the reform blueprint Anderson also served on the panel. However, the Professor of Oriental Laws did not take on a formal leadership role in the panel's work-although Anderson had originally been the Colonial Office's choice for panel chair, that nomination was been withdrawn following accusations by Northern Nigerian elites that he was a "zealot" bent on eliminating Islamic law. ${ }^{81}$ Even without his formal leadership, Anderson continued to drive the panel's direction. In fact, it was the oriental laws expert who drafted much of the Penal Code that formally replaced Islamic criminal jurisprudence, completing the stealth process that began in 1903 Lugardian Northern Nigeria. ${ }^{82}$

In seeking the wholesale import of the imperial Sudan Code, the Panel's work spanned Islamic criminal jurisprudence. Nevertheless, the issue of diya came to assume a central place in the negotiations. Citing diya and afw's express grounding in the Quran and Sunnah, Northern Nigerian elites insisted that the institution could not be eliminated even if a code of criminal law was to replace the rest of Islamic criminal jurisprudence. In the lengthy discussions that followed, securing the assent of the Northern Muslim elites took the intervention of an expert with just the right credentials: the Mufti of Sudan, Sheikh Mohammed Abul Gasim. Upon the invitation of the Northern Nigerian Colonial government, Mufti Abul Gasim set to work to convince the northern Nigerians, arguing that the preclusion of diya was permissible in Islamic law. ${ }^{83}$ The Mufti drew on the Quran, Sunnah and several juristic texts to assert that the Imam's siyasa powers encompassed the preclusion of diya and compulsory imposition of punishment. As noted earlier, the dominant strand of precolonial and colonial juristic thought drew from classical Maliki thought to suggest that the payment of diya could be accompanied with a ta'azir punishment as long as it was radically less than the death penalty and preferably not exceeding 1 year/ 100 lashes. However, Mufti Abul Gasim's went beyond the maliki position by suggesting that diya could be entirely precluded and by setting no limits to ta'azir penalty. Like Anderson, the Mufti's position was that the state could compulsorily impose all penalties including the capital punishment regardless of

\footnotetext{
${ }^{80}$ In an effort to have non-Muslim representation on the panel, the government appointed Peter Achimugu, a Christian and prominent political elite and government minister to the panel.

${ }^{81}$ Bryan Sharwood-Smith to John Macpherson, 17 August 1957, NA, CO 554/1941, p. 37.

82 The colonial administrator who had a significant influence on the code's drafting, although not comparable to Anderson's impact, was SS Richardson, lawyer and commissioner for native courts in Northern Nigeria.

83 Attorney General H.H Marshall to the Panel of Jurists, September 10, 1958 in Philip Ostien ed., Sharia Implementation in Northern Nigeria 1999-2006: A Sourcebook, Vol. I (Ibadan, Nigeria: Spectrum) 59-60.
} 
the wishes of the victim's agnates. Even more importantly, the Sudanese jurist legitimized this shift from the prevalent juristic position by invoking the "Imam's" Sharia powers as Anderson did. Following Anderson, Mufti Abul Gasim, therefore suggested not only that the (late) colonial state had come to take the place of the Imam but also that the colonial state's siyasa powers could exceed the constitutional boundaries of the Sharia as determined by fiqh. Crucially, Mufti Abul Gasim, as Anderson before him did not imagine this siyasa to be a violation of the Sharia; rather, it was a siyasa that in some sense could define what could be legitimated as the Sharia.

Northern Nigerian jurists regarded this argument as dubious; together with political elites, these jurists disputed the Penal Code's legitimacy. For instance, Haliru Binji, a young Maliki Law scholar educated in the customary madrasah, and later at the School of Oriental and African Studies, insisted as did several other noted scholars that the reform was "unislamic." ${ }^{84}$ Political elites' opposition to the reform project was led by Sir Ahmadu Bello. ${ }^{85}$ In a nudge to these sentiments, the Code's preclusion of diya provided one exception: that diya could in theory be a justification for reducing a sentence in cases of unintentional homicide. It was never to be an alternative to punishment as applied in precolonial jurisprudence. In cases of premeditated murder, the wishes of the relatives of the victims to absolve the convict of criminal penalty could not lessen the penalty. Rather, it was to be recorded by the court to become relevant in circumstances where the prerogative of mercy was being contemplated-by the state. In essence, diya was never to substitute for state's punishment. It was rather, "a means for readjusting the social equilibrium" upon "the conclusion of a case" on terms determined by the state. ${ }^{86}$

\footnotetext{
${ }^{84}$ This was regardless of the fact that Binji was himself formally involved in the processes leading up to the panel's work. Binji had served on the colonial state nominated delegation to study the modernization of the legal systems of Libya and Pakistan. See SS Richardson, No Weariness supra. Inspite of this opposition, Binji and another fierce critic of the reform process, Abubakar Gumi, would serve on the court created by the 1958 reform processes-the Sharia Court of Appeal established to adjudicate disputes arising from those areas of Islamic law retained that is non criminal law. he reform design's separation of Islamic criminal law from other aspects of law and eliminating the former. See John Paden, Ahmadu Bello, Sardauna of Sokoto: Values and Leadership in Nigeria, (Zaria: HudaHuda, 1986), Gumi, where I stand, id.

${ }^{85}$ As Sardauna, a prominent title-holder of Sokoto, Bello was both a representative of the old elite class while being the foremost indigenous political elites in the late colonial state's institutions. If these elites were particularly agitated by the state's project to reform diya, they denigrated the reform proposal as a whole. "Islam," these elites declared, is a "a total way of life" and to take away part of it, even in the domain of criminal law, would undermine the whole religion. Anderson, Conflict of Laws in Northern Nigeria, p. 451.

${ }^{86}$ Panel proposal 14, Ostien vol-6. Chap 1 part iii p. 35-6
} 
In the end, however, even the staunchest opponents to the code among Northern Nigerian elites latched on to arguments advanced by Anderson and Mufti Gassim, arguing like the later that the Northern Nigerian government could exercise siyasa powers to enact a code precluding diya as Muslim states like Sudan had done. Introducing the Penal Code bill on the floor of the Northern Region House of Assembly, ${ }^{87}$ Ahmadu Bello declared: "there is nothing in the [code] ... that is in any way contrary to the tenets of our religion," and cited the code's acceptance by "the millions of Muslims" of Sudan and Pakistan. Arguing that the legislation had "... preserve[d] the fundamentals of Islam" 88 in a manner compatible with a modernity, Bello went on to urge the legislative assembly newly created by the colonial state to adopt the Code. In fact, by the time Bello was urging the legislative assembly to ratify the Anderson designed reforms on what was the eve of Nigeria's independence, that body had to come to overwhelmingly comprise of indigenous political elites like Bello. These new elites they were not unconnected to the old power structures - in fact, even Bello was himself a prominent title holder-the Sardauna of Sokoto. Consequently, although the diya reform project was a colonial agenda and British administrators and their experts continued to hold the lever of power even in these late colonial years, indigenous elites were not completely excluded from the recalibration of siyasa power. In December 1958, two years before Nigeria became Independent of the British Crown, the Northern Region House of Assembly passed the Penal Code Bill into law. By this legislative act, siyasa was wielded to codify the preclusion of diya that had begun since the early days of the colonial state.

\section{Conclusion}

More than the elimination of diya, what was striking was the constitutional structure through which the reform was effected. For all of empire's avowal of its deference to Northern Nigerian Islamic institutions as the vessels of colonial indirect rule, the colonial state radically transformed those institutions. That this occurred in the domain of the law of homicide should hardly be surprising; empire, like all sovereigns claimed the right of life and death. In fact, the general rule, across the British Empire, was for the state to shed even the pretense of applying Islamic law as criminal law.

\footnotetext{
87 The colonial state established the House of Assembly in the late colonial years as a step towards eventual decolonization

${ }^{88}$ Ahmadu Bello, "Speech to Assembly on legal Reforms on December 12, 1958" in Bello, Work and Worship, 222. On Bello's oscillation between 'reform' and 'tradition,' see John Paden, Ahmadu Bello, Sardauna of Sokoto: Values and Leadership in Nigeria, (Zaria: HudaHuda, 1986).
} 
The state's efforts to maintain appearances of retaining the juristic principles concerning homicide and particularly that governing diya sprung from a desire to avoid open confrontation with emirs, alkalai and jurists. In furtherance of this ceremonial deference, the state embarked on a siyasa transformation project, first precluding diya through state-expanded emir's siyasa powers, and radically transforming the pre-colonial constitutional balance between emirs and jurists. When the emirs were spurred by changing and complex political conditions to rebel against the colonial project, colonial officials crafted a novel argument legislating the outright elimination of diya. Although it was effectuated through a state codification process, the elimination of diya was legitimated in the same way as the Emir-channeled reform - as a justifiable exercise of the late colonial state's siyasa jurisdiction. Astonishing as it was, this argument was tremendously successful in transforming the constitutional boundaries of the siyasa. From its prior conception as a siyasa legitimated by the sharia (however idealized and susceptible to being transgressed)-siyasa Shariyya-siyasa came to be legitimate sharia claims. It is this constitutional transformation that has endured, surviving colonialism and finding expression in nascent postcolonial attempts to reinstate Islamic law through the machinery of state institutions bequeathed by empire. ${ }^{89}$

${ }^{89}$ See Asifa Quraishi-Landes, Islamic Constitutionalism /d, Rabiat Akande, Dissertation id 
Rabiat Akande 11/02/2021

Draft; do not cite without author's permission 